\title{
Dynamism of Religious Dialogue (Inter-Faith Meeting) and the Growth of Christianity in Nigeria
}

\author{
Godwin Viwala \& Ben O. Onu \\ http://dx.doi./org/10.4314/ujah.v20i2.5
}

\begin{abstract}
Religious diversity is a possible feature of any human society. Even in a religious homogenous society, there are factions and sects within a particular religion. The diversity in religious conviction gives rise to a lot of options based on religious inclination. The society in which the religion is practiced need to be at peace for the religion to thrive and be propagated hence, dialogue is necessary as to see how the orthodoxy and orthopraxy can lead to peaceful co-existence as they define the societal norms and values. It is in this respect that this paper examines the issues of dynamism of religious dialogue or interfaith meeting in the light of growth of Christianity in Nigeria, being a multi-faith, multi-ethnic and multi-cultural society Using the historical and phenomenological perspectives, the paper found out that since the $19^{\text {th }}$ century inter-religious dialogue have been in progress and will need to continue. The foundation for religious dialogue and peaceful co-existence was laid by Chief Shodeke on December 51842 in Abeokuta when the three contending religious leaders - Islam, traditional religion and Christianity were invited to explain their philosophies. It was discovered that inter-religious dialogue melts the walls of in-difference and enhances understanding of the religious world view. We therefore conclude that inter-faith dialogue which offers opportunity for understanding and respect of non-Christian neighbours should be sustained for the acceptance and growth of Christianity in Nigeria.
\end{abstract}

Key words: Dynamism, dialogue, ecumenical, inter-faith, growth. 


\section{Introduction}

This paper examines religious dialogue from a historical and phenomenological perspective. Considering the various religious riots, and animosities that ravage our country by adherents of various religions, there arise the need to see how these things can be controlled. Looking for solutions to religious problems outside religion itself is a hoax, since issues of faith is a people's life. In Africa, people are so religious that Arthur G. Leonard once wrote; They are, in the strict and natural since of the word a truly and a deeply religious people of who it can be said, as it has been said of Hindus, they eat religiously, drink religiously, bathe religiously, and sin religiously. In a few words, the religious of these natives as in have all along endeavoured to point out is their existence, and their existence is their religion (1906:429).

The recognitions of what religion does and is doing and will continue to do in the society is a matter of concern, since nearly every year new religious movement springs up within Christianity and other religious. Some of these sects have a more fundamental approach to the interpretation of their convictions on how to run society. These convictions often lead to extreme behaviours and a times acts of violence is carried on other people who do not profess their faith.

Even within a particular religion, new groups spring up with leaders that will want to force their will on the members. This they do claiming the others have derailed from the fundamentals of their teachings, so they (the new group) have a more accurate application of their scripture, thereby posing another intra as well as inter religious danger, referred to as "fundamentalism". In an attempt to proffer solution to this problem which is multi-faceted 
group can resort to religious dialogue. This involves explaining their convictions, practices and application to the society, and will make adherents to understand the point of view of others and live peaceably with each other in the society. The work traced the history of religious dialogue in Nigeria, how it has helped and so line.

\section{Religion and the Society}

Religion is the life of any society. In fact, there is hardly any human society that is without a form of religion. Religion has been considered by some as the loftiest, most profound expression of human spirit. Others see it as a blight on civilization, responsible for superstition, ignorance, hatred, repressing even genocide as religion and history display a mix of spectacular success and abject failure (Oxtoby, 2002:1-2). Viewing religion from the above, places one between two extremes, either forsake religion or accept it. At both extremes man is at the centre because they play out the society where man leaves. Therefore, no society can expunge religion whether inspired or reveal and expect to function well. This is because man needs more than biological satisfaction which is found in food, shelter and sex. Beyond these, he needs rational, moral, social, aesthetic understanding for he is a solution of nature and spirit. There are five importance of religion to the human society, namely; to obtain material benefits such as food, crop yield, good health, life itself and everything that religions hope to get, obtain protection against supernatural and mysterious powers and forces which tend to inflect fear on mankind, explain the existence of humanity or origin of the universe and the things that are there in, justify certain actions of man in the society, and re- 
force accepted social values and norms (Wotogbe-Weneka, 2014, citing Carton,1973: 53-56).

The human society is the theatre of religions both its orthodoxy and its orthopraxy. In most cases, religion became the measure of patriotism, and the societal barometer to maintain orderliness in a society. Religion as practised by man in the society, has both positive and negative effect as it affects our habits, dressing, eating, interactions with each other, care of the environment, political, economic and even international relations in commerce, the list can go on. In sum, religion is the matrix of the society. Thus, a society without religion is a society not worth living; fortunately, there has been non-known in human religious history.

\section{Antecedent to Inter-faith Dialogue in Nigeria}

Though the evangelical revival of the late eighteenth century in England, which owes much of its work to John Wesley, Charles Wesley and George Whitefield, the Wesleyan Methodist missionary society was established in 1813 for the support of overseas missionary work (Ian Fleck (2013:41). The missionary society offered opportunity for young Christians to be trained for missions outside Europe. The Rev. Thomas Birch Freeman who was born in England, his father a freed African slave and mother an English woman applied to the Wesleyan Methodist missionary society when he was twenty-eight years old(Agbaje, 1955: 2). The Wesleyan Methodist missionary society committee gladly accepted Rev. Thomas Birch Freeman's application, perhaps thinking that as he was the son of an African father, he could be more resistant to the climate than others who had gone before (Fleck, 2013: 42). The application and its acceptance by the Wesleyan Methodist missionary committee was a divine providence for Freeman to 
work in Africa, starting from Gold Coast (Ghana) to Sierra Leone and finally Nigeria. Freeman lived to be over eighty and only twice he returned to England during the fifty-two years he spent in West Africa. Freeman's first appointment in Africa was not in Nigeria, but before leaving England for Africa he Furthermore, Fleck I, (2013: 42) stated that, Freeman, as part of his preparation for missionary work, Thomas Birch Freeman was ordained into the Methodist ministry on October10, 1837 and the following week he married. His first appointment with his wife was to the Cape coast castle, Gold coast (Ghana) in January 1838, where the Methodist ministry had begun work in 1834. On arrival, they found themselves alone, as George Wringley who was working there died weeks before. This meant that all the first five Methodist missionaries to the Ghana had died due to the difficulties of the climate. With no missionary colleague to support him, Freeman very quickly got involved in the work of preaching using interpreters. He made converts among the freed-slaves who had settled in Sierra Leone who had become traders and joined the church in Ghana. In their trading along the coast from Free-Town to Badagry, some of them recognized the place and market they were shipped from, and even people they traded with spoke their mother tongue (Yoruba) language. They could hear their people discuss about the war in Abeokuta.

On reaching back to Free-Town they discussed their experiences with their colleagues and also reported the warm reception they received on reaching Abeokuta. The report made a number of the freed slaves of Yoruba origin to consider leaving Sierra Leone for their homeland. Between 1839 and 1847 an estimated number of about 500 (five hundred) returned. This was the group that formed the elites of the town and started demanding 
for missionaries to help them carry the gospel to their own people. In1841, Rev Dove the superintendent of the Methodist mission in Sierra Leone, said he had received two letters from emigrants in Badagry inviting missionaries to visit them urgently. According to Fleck;

The desire of the emigrants was that the gospel of God our Saviour may be preached unto her, that schools may be established, that bibles may be sent, that the British flag may be hosted, and that she may rank among the civilized nations of the earth (2013: 43, citing Crowther 1978: 114).

Since the emigrants were not ready to wait in Sierra Leone any longer, and were very eager to join their kinsmen in Abeokuta, the Methodist mission had no alternative than to send a missionary. After careful examination, Rev. Thomas Birch Freeman was called from Cape Coast to move down to Badagry. He arrived with his wife on September 24, 1842marked the beginning of missionary work in the geo-political entity called Nigeria. Thus, the first mission station in Nigeria was established by a man who was half African. Freeman's first point of call was in Badagry. However, he did not find Badagry better than the days of Richard Lander of the expedition organized by Macgregor Laird in 1832.This is to say that apart from being a slave port, Christianity was yet to touch the native people. Notwithstanding, the negative practices of the people, Freeman bought a piece of land and proceeded to build a chapel with local materials (bamboo) and also mission house with planks. The missionary was now living in the constant fear of possible attack on Badagry from Dahomey (Benin) and also Abeokuta. However, he continued his work of building a befitting living home which he described as; 
alarge, airy dwelling house, fit for a European family, raised from ten to twelve feet from the ground, on twenty-two stout coconut pillars, averaging about three quarter of aton each in weight... It appeared a thing so novel and extraordinary, that the people were often seen standing in groups at a shirt distance, gazing at it in astonishment (Ajayi 1965: 31, citing Freeman Journal of various visits...).

As the work of building was over, he got an urgent call from Chief Shodeke of Abeokuta. On December 5, Chief Shodeke sent fourteen men to escort Freeman accompanied by Mr. De-Graft to the town of Abeokuta, about eighty-miles North-East from Badagry. The journey was not an easy one considering the transport system way back then. However, on December 10, 1842, the team from Badagry reached a community called Owayadi on a hill near Abeokuta, Freeman's destination. Emigrants from Sierra Leone that initiated his invitation came to greet him speaking to him in his own language where numerous native greetings were offered. It was late so Freeman rested on a farm settlement of Okwaru for the night. Reporting about visit, Fleck citing an online achieve document states thus;

At six O'clock on Sunday morning a mounted escort arrived to conduct the missionary and his party over the river Ogun and the few miles into the town. As he passed through the streets a chorus of native salutations greeted him. "welcome, welcome!" the crowd increased as he proceeded, and the salutation grew louder, till he was brought into the compound of the great chief, who held the supreme position in the plutocratic government of this native state (Fleck,2013:46). 
Freeman's arrival gave rise to the first inter-faith or religious dialogue in Nigeria. In the first instance, there was need for the elites of Abeokuta to write a missionary. Secondly, Chief Shodeke invited all religious leaders and practitioners to be part of the meeting which they agreed. This brought together Chief Shodeke with leaders of the three contending religions namely Islam, traditional religion and Christianity in his domain invitation.

An historic meeting, which was attended by the traditional priests, the Muslim leaders, the ex-slave Christians, the chiefs of the town and Freeman himself, was then summoned by the king Shodeke to his Courtyard. This meeting witnessed a kind of religious debate between Freeman, Muslim leaders and traditional priests during which they had to explain their religious beliefs one after the other. The explanation given by Freeman impressed the king so much that he concluded that the white man's religious was the one to follow. So, from the court yard of Chief Shodeke in Abeokuta the first religious debate or dialogue took place in Nigeria on December 10, 1842 (2013: 47).

\section{Need for Dialogue in Christian Enterprise Today}

As the colonist entered into Africa they met a very religious society. They took upon themselves to re-orient the African and direct them to the Christian religion as practiced in their home countries. This is a fact which king Leopold II of Belgium attests to when he said, Reverend father and dear compatriots, the task that is given to you to fulfil is very delicate and requires much tack. You will certainly evangelize but your evangelization must require above all Belgium interests. Your principle objective in mission in the Congo's never to teach the niggers to know God, this they know already. They speak and submit to Mungu, one Nzambi, one Nzakomba, (African gods) and what else I not know. They know 
that to kill, to sheep with someone else's wife, to insult is bad. Have courage to admit it are not going to teach them what they know already (Naiwa Osahoa).

So, this attempt at trying to introduce Christianity into Africa with national interest brought about religious conflicts in Africa. In Nigeria, this started long ago. The first recorded religious dialogue took place in Abeokuta when Thomas Birch Freeman arrived in Abeokuta missionary work. He met with Shodeke king of Abeokuta. According to Fleck Shodeke clasped Freeman in his arms before all the people showing his great satisfaction to have him, and said;

My people told me they were sure their friend in England would not neglect them, but I feared you would not venture come so far. Now i see you, and my heart rejoices, and as you have now come to visit us, I hope the Englishman will never have us (2013: 47).

Reaching Abeokuta, and the warm reception accorded to him by chief Shodeke all was set for an inter-religious dialogue. This historic meeting held on Dee. 10, 1842was attended by the traditional priests, Muslim leaders, ex-slave Christians, chiefs of the town and Freeman himself. The meeting, though primarily called to welcome Thomas Birch Freeman, eventually ended up in the king calling on the religious leaders present to explain the tenets, practices and other issues pertaining to their different religions. They all did this one after the other. Freeman used the opportunity to expound the scriptures, Shodeke himself seated beside him, and for the King's benefits, all that was said was interpreted into Yoruba language. At the end, Sodeke concluded that the white man's religion was the one to follow. The meeting paved way for religious interaction and understanding. This could 
be regarded as the precursor of why in Abeokuta and all Yoruba land today enjoy peaceful co-existence of traditional, Islam and Christianity. Olabiyi Babalola Yai (1992) in his preface to the book entitled Religions and peace in Multi-Faith Nigeria States that;

The role of traditional ruler in inter-religious dialogue in Nigeria is a model in ecumenical academic discourse. The scholar king set the tone of the conference by declaring", I make bold to say, now I am a Christian, a Muslim and a worshiper of Ogun, Obatala and other traditional deities. That is the essence of being Oba, the essence of preserving and promoting inter relations dialogue, the theory and practice of a "secular state system, "the Yoruba style".

The effect of that meeting is now a practical reality and an example to follow inter-faith dialogue in Nigeria. Since king Shodeke led religious dialogue in Abeokuta, the expansion of Christianity was tolerated in Yoruba land at least. But developments from other parts of the country, the North and middle Belt especially were that of confrontations. The king Shodeke model was not shared by rulers in other lands. Christianity entering into Northern Nigeria was based on misguided information and lack of understanding of the depth to which Islam had taken root in the regions.

Ayandele (1966:17) opines that although evidence points to the fact that in Yoruba itself statistical progress of Islam was considerable, and occasionally alarmed missionaries, it was the Sokoto Caliphate on which missions, fixed their eyes as the real battle ground where they should enlist against missions. Without an attempt at understanding the people and their religious convictions. He went further to opine that there grew a myth, an illusion in the Church Missionary Society (CMS) circles that the Northern Nigeria peoples, including Muslims would be easy to 
convert. When reality dawn on the party that left Manchester in trying land to change the Northern Hausa into Christian considered in a short time had failed, the missionaries turn to political propaganda for the British government to annex the North militarily so that under that cover Christianity could penetrate the North. The mistake here that the missionaries made was looking in the direction of political and military power to propagate the gospel, dialogue would have been the best option.

Ayandele (1966:125) went further to say that by 1897, the church missionary society (CMS)with many of its missionaries had begun to look forward to a military subjugation of Northern Nigeria, which event they hoped would as in Southern Nigeria, opened the door for the Christianisation of Northern Nigeria. The expectation of the CMS was quite legitimate for as analysed so far, the "Sword of Stell" and the "Sword of the Spirit" had been going together in the experience of recalcitrant Nigeria peoples who attempted to prevent infusion of either the missionary or the administrator into their area. In Northern Nigeria, the CMS expected the British bayonet would remove the Fulani "imposters", the main obstacles, as if seemed to the missionaries, to evangelization of the territory, is not surprising then that the society interpreted military expenditure against Ilorin and Bida as the beginning to the fulfilment of their hopes. However, on the side of the African traditional worshipers some form of dialogue was made and directed to the holy see of Rome and the Archbishop of Canterbury.

Chief K.O.K Onyiola In (1975:375-407) Says,I am happy to report at this juncture that following these protests of the Godian religion to the pope and Archbishop of Canterbury against this Christian artistry in which all the evils with the inmates of his hell 
were painted black while God with all the inmates of this heaven were painted white. Christianity produced new pictures, which were sold in Port Harcourt market by the Catholic Mission for the first time in 1960 with some of the angels of heaven painted black while the majority, however were painted white. This understanding by the Godians (ATR) of Nigeria and not resorting to violence or of friction with either Islam or Christianity made them have their way into Christianity as K.O.K Onyiola further stated, we communicated our canonization to the Pope and Archbishop of Canterbury and asked them to take note of our own candidates for heaven. This smarted the Pope to canonize the twenty-two Ugbndan Martyrs who had been left in the fringe of purgatory for nearly a century with climbing them martyrs were catapulted into heaven. Under the pressure of Godianism, Christian churches catholic and protestants a like-are now making strong moves to form what is to be known as the United church of Nigeria and are already worshiping together occasionally.

Roman Catholic mass started to be said in African languages when Godianism began to protest against the saying of mass in Latin only, as if Latin is the only language of the Gods, and as if God does not understand African languages. Under the pressure of Godianism, Christianity now accepts African names for baptism, sing African songs and beat African drums at church services and allows those who hold African traditional tittles to take Christian communion. K.O.K, Onyiola (1975: 387-407) furthermore,

Christianity had rejected everything African as offending to God, but under the pressure of Godianism, Christianity is now accommodating and adapting itself to African traditions.Masquerades which were earlier condemned as heathenism, unwanted by God now perform during Christian 
festivals (KOK Onyiola 1975:387-407). When dialogue is neglected, it only leads to animosity, which if not properly handled breaks down into chaos. It can be said neglect dialogue and welcome crisis welcome dialogue and welcome peace.The traditional rulers (ATR) reiterate through the voice of his Highness, Oba (Dr) S.O Babayemi the Olufi of Gbongan", that traditional rulers have a responsibility to the nation in enhancing inter-religious dialogue.

Throughout history, religion has been a source of development as institutions like the church were among the first to provide asylum for accused criminals. The actual establishment of prisons and penitentiaries was a religious idea to allow the offender to obtain penance for his/her crime and make amends while being isolated from others. The prison services provideda religious chaplaincy service for inmates of correctional centres to help them to fit back into the society after serving their sentences. Imaekhai (2010:29) went further to say that ethnical conduct in leadership breeds a trusting relationship among the participants, be they in a company, political constituency, family or government. Also, Hatfield says "religion is a critical factor in society for development priority,', Olupona (1992: 1) observed that, religious factors as an important variable in all aspects of our national life is real whether in the appointment of ministers of the state, or even national elections. It will be mere wishful thinking to assume that we run away from this significant event on the eve of Presidential elections. As the elections came closer, the rate of prophetic predictions and forecast about the future President increased. The whole fabric of Nigeria's national policy is saturated that every worship day, one government officer or the other worship with them. Ayawei (2005) also observed that religion was however the 
central pillar and plank used by the colonialists to take over governance of the various units that make up what is known today as Nigeria. And it was the Christian religion that opened the gates of mass media in the country. The importance of religion in national development cannot be over emphasized as it shapes even our national orientation even from colonial days.

In Nigeria, several faith-based organizations respond to adherents and others alike in times of disaster, both natural and man-made such as wars. They include Christian Council of Nigeria (CCN), Christian Association of Nigeria (CAN), Adventist Disaster and Relief Agency (ADRA), Nigeria Supreme Council for Islamic Affairs (NSCIA) and CARTAS, all exist to help government and people in times of national calamities and development. So in a multi faith religious society like Nigeria, the understanding that when disaster strike it is not selective of a particular religious persuasion, should make enough room for religious dialogue. The on-going Boko-Haram serge in the North Eastern part of the country now though a sect Islam have affected Christians, Muslim and others alike. To help government, various religious relief agencies have sent in food items from different parts of the country to these internally displaced people (IDPS) in their Camps. When these clothing and other items get there, they are not been distributed according religious inclinations. In fact, all of them stay together peacefully recognizing that no matter the religious conviction they all face the fate. The realization, that in spite of our religious persuasion we leave Mosque, Cathedrals, temples, shrines and leave next door to the other person should make Nigerians, not them alone to consider the issue of religious dialogue as a matter of collective concern. 


\section{Religious Dialogue as a National Agenda}

No one living in Nigeria from the colonial era till now will claim ignorance of what religion has done and is doing in the Nigerian society. Ikenga-Metuh (1992: 20) opines that the thesis that religion is sometimes one of the major causes of wars is borne out of the fact that some of the current international and intra-national conflicts have religious overtones. The Arab/Israeli conflict, Iran/Iraq war, civil war in Sudan, Lebanon, and Northern Ireland are all fought under religions banner. Near home, the Maitatsine disturbances of 1980, 1982 and 1984 and religious turbulences in Kaduna State in 1987, and incessant attacks on churches were great threats to peace in Nigeria. The various religious disturbances have increased the call on the government to have a re-look at the issues involved in each disturbance, thereby bringing the religious dialogue to the fore front as a national agenda.

There were incidents which occurred between 1976 and 1980, which threatened to turn the uneasy peace and suspicious between Muslims and Christians into open conflicts or even violence. These were the question of introduction of Federal Sharia Court of Appeal in 1978, burning of Christian buildings by Muslims in Kano in 1981and 1986, and Nigeria membership of the Organization of Islamic Conference (OIC). After some hot verbal exchanges followed a meaningful dialogue, some compromises were worked out on the Sharia question which provided for a chamber in the Federal Court of Appeal to hear appeals from State Sharia Courts of Appeal. Furthermore, in a heterogeneous and multi faith nation like Nigeria, any attempt to impose a belief system or its philosophy on the others will for sure breed disharmony and endanger the peace of the society. Hence, the road to harmony and peaceful co-existence in a pluralist's society like 
Nigeria is dialogue. In Nigeria today, dialogue is more needed than ever to "open many doors closed by tension that have marred (inter-faith) relations". The government and scholars are to dig deep into religious dialogue as a national issue for peaceful coexistence of Christians, Muslims and traditional worshipers.

The knowledge of these have made some scholars and people of good to set up formal avenues for inter-religious dialogue. The Nigeria Association for Religious Tolerance (NARETO) and the Nigeria-Muslim-Christian dialogue are a few of such organizations. Any government that comes to power in Nigeria and neglect religious dialogue in its scheme of things may be doing so at its own peril (Manus, 1992:4-5). As Takaya (1992: 109-123) pointed out, it makes no sense to discuss the modalities of bringing about religious tolerance for peaceful co-existence and co-operation in a multi-religious Nigeria without first understanding the worldview of the two received religious faiths to appreciate the motive force that informs and impel them to political action. To further see how the religious dialogue have become important in national issues affecting both our economy and political appointments. Buka (1992) highlights that the economic difficulties are being accompanied by the incidence of religious intolerance and revolts beginning from the Sharia campaign of 1977/1978, when for the first time a religious crisis took a national dimension, the Maitatsine revolts of $1980-1985$, the IOC controversy of 1986, to the Kafanchan religious disturbances in 1987. From1988-1989 when the economic crisis reached its apex, some unfolding issues appear to stress the need for religious dialogue. These include, the deadlock over the selection of Chairman and Secretary for the Advisory Committee on Religious Affairs (ACRA) by the country's leading Muslim and Christian leader, questioning of the religious status of Abuja as 
Nigeria's new federal capital, the Sharia debate, the Constituent Assembly in Abuja, the ABU Students Union election, religious fracas, revolt by the Sokoto masses over the imposition of Sultan Dasuki as the chief of Muslims, "SarkinMusulini", the boos and insults which president Babangida personally received from Muslim worshipers at Sultan Abubakar Mosque in Kaduna, to the religious controversy which surrounded the Federal Government Cabinet chiefs. Religion from inception has played and will continue to play a role in our national life and must be addressed as part of the national agenda.

\section{Gains of inter-faith dialogue in Nigeria}

Ever since the king Shodeke'sinter-religious meeting in Abeokuta, though not replicated in most part of Nigeria, yet the country has some gains from inter-faith dialogue. Baur (2009: 415) opines that the Islam in Africa Project Council, including a number of Protestant groups was founded in 1959. Its purpose was "to prepare Christians for their encounter with and responsibility toward Muslims in Africa South of the Sahara". In 1965, it opened a study centre for Islamic choirs, and through the Association of Theological Institutions the subject has been introduced in the syllabuses of major seminaries and theological colleges in Africa.

The gains of inter-faith dialogue can be seen in Yoruba land. Abubakar (1992: 124-13) talked of Muhammad Jimoh (19461959), the Mahdi of Ijebu-Ode, who took a step to combine African Traditional Religion, Christianity and Judaism with Islam. He had a cross imprinted on the batches of his followers and the same is printed on his Mosque. He held the cross as one of his insignia, and claimed to know the meaning of the cross even more than Christians. He has what he called the art of covenant, a tablet 
on which the creedal statement is written with an assertion that he is the Maldi. With observance of Islamic rituals, the mixing of the bits of ATR with Christianity and his belief in some relics of Judaism, he achieved a kind of synthetic religion. This could not have happened in an atmosphere of religious bigotry. Manus also asserts that a great deal of social justice have been achieved through religious dialogue at the national level. According to him;

Great transformation has occurred in the levels of individuals, nationals, churches, and Institutions in this country, Social scientists are consistently telling us that our Nigerian Society has seriously been visited by change agents associated with the advent of the Islamic and Christian religious (Manus, 1992: 40-53).

From the study of the Qur'an and the Bible, various peace passages in both sacred writings can be applied to the Nigerian situation. Sam Babs (1992:) observed that the Qur'an has inclusively shown that peace is bound with faith in God. The Qur'an declares "Oye who believe enter into peace (Islam), all of you," (Q.2: 208).Christians are similarly summoned to submit to God. Jesus Christ unequivocally restates, the cardinal commandment of God is: "you shall worship the Lord your God and only him shall you serve" (Matt. 4:10, Deut. 6:13). The Bible like the Qur'an affirms God as the source of "all peace" (Isaiah 45:7).From the foregoing, it can be said that inter faith dialogue on both national and private life issues leads to a better understanding of each religious philosophy, respect and tolerance that eventually ends in peaceful co-existence which is a gain to both individuals and nations. 


\section{Religious Dialogue and Growth of Christianity in Nigeria}

No religion can be propagated successfully in a society where there is rancour and disorder. Christianity is expected to make gains through religious dialogue in Nigeria. We had seen earlier in this work how the early missionaries to Northern Nigeria and could not accomplish much in the conversion of predominantly Muslim community, as a result they resorted to calling on political authority with military undertone. That rather than produce expected result ended up making the people tougher and more resistant to Christianity. However, when a new and subtle approach was applied, Christianity started penetrating the area.

The positive effects of the dialogue approach can be seen in the work of Bishop Samuel Ajayi Crowther. Dauda and Gbule (2000:72) remarked that in 1857, Samuel Ajayi Crowther planned the evangelization of Northern Nigeria using conciliatory approach. He befriended the Emirs and sought their permission and protection for his work.Asa result, he established mission stations at Lokoja, Egbah and Kippo hills. He was able to persuade the Emirs of Bida, Ilorin, Gwandu and Sokoto to accept the Arabic Bibles. By 1880, both the CMS and Methodist had expressed a strong desire to establish a station in the North.

The growth of Christianity into Northern Nigeria in recent times cannot go without a strong reference to inter-faith dialogue which the federal Government have put in place, such as, Nigerian Association for Religious Tolerance (NARETEO) and NigerianMuslim-Christian Dialogue. These have helped to reduce tension between the two contending religious as they been able to eradicate animosity. Formally, Muslims who were antagonistic to Christianity based on ignorance of the teachings of the religion can now tolerate Christians. Christianity is engaged in some creative 
ways of approaching people of other religious persuasions. N. S. S. Iwe maintains that;

to be creative, religion must be original, pioneering, exploring and self-reforming and reinforcing, renovating and restricting itself in all efforts to relate itself to the needs of the people. Its creativity will lay it open to ideas with a readiness to accept and effect reasonable and salutary changes as the spirit of the times and culture may require (1979:49).

Counting the gains of religious dialogue and understanding among the three religions of Islam, Christianity and African Traditional Religion, Olupona (1992:5) says as a keen observer of the interactions of religion, culture and society in Nigeria, tradition has continuously adapted into its own system, elements from some of the most cherished religions symbols and customs of other traditions without necessarily showing any sign of syncretism. For example, pilgrimage to the holy land which is a cardinal ritual for Muslims, has become quite prominent among Christians even when it does not make for salvation in Christianity. These days, the common title of J.P.(Justice of the peace) could also mean (Jerusalem pilgrim). It is also a common knowledge that Muslims have imbibed and appropriated some Christian local traditions such as father Ileya and a popular Christian lyric."Ose O Jesu, (Thank You Jesus) as "Ose O Allah. (Thank you Allah).

Godwin Viwala \& Ben O. Onu

Department of Religious \& Cultural Studies University of Port Harcourt. 


\section{References}

Abubakre, D.R. (1992). Religion, Culture and Politics among the Yoruba Muslims. In Olupona, J.K (ed). Religion and Peace in multi-faith Nigeria. Ile-Ife: OAU press.

Agbaje, A. A. (1955). Thomas Birch Freeman (1809-1890). InOmoyajowo, J. A.ed. Makers of the church in Nigeria. Lagos: CSS Bookshops.

Avawei, P., Abila, S. and Kalama, S. T. (2015, Aug 25). Media and Religious crisis in Nigeria: A resonance. https; / / prompt! Org (me mo. mokhta Award: George Washington University. Accessed: 19-04-2017. 11.48am

Ayandele,E.A. (1966).The missionary impact on modem Nigeria 1842-1914: A political and social analysis. London: Longman.

Bako, Sabo (1992). World economic recession and the growth of religious intolerance in Nigeria. In Olupona, J.K (ed). Religion and Peace in multi-faith Nigeria. Ile-Ife: OAU press.

Baur, J. (2009).2000 Years of Christianity in Africa. An African church History. (2Edn). Kenya: Paulines publication.

Dauda, M. and Gbule, J. N. (2000).An outline of the history of Christianity in West Africa. Zaria: Micsons press and publishers.

Fleck,I. (2013). Bringing Christianity to Nigeria: The origin and work protestant missions. Bukuru: ACTS

Ikenga-Metuh. E. (1992). Religion as instrument of peace in Nigeria. In Olupona, J.K (ed.). Religion and Peace in multi-faith Nigeria. Ile-Ife: OAU press.

Imaekhai, F.J. (2010). The importance of religion in Nigerian society. InIsiramen, C. O. (ed.). Religion and the Nigerian nation some topical issues. Ibadan: En-Joy Press \&Books. 
Iwe, N.S.S (1979). Christianity, culture and colonialism in Africa. Port Harcourt: RSNC.

Lenard A.G. (1966). The lower Niger and its tribes. London: Frank Cass.

Mala, S.B. (1992). Peace passages in the Qur'an and their implication for inter-religions relations. In Olupona, J.K (ed.). Religion and Peace in multi-faith Nigeria. Ile-Ife: OAU press.

Manus, C.U (1992). Religions values, social justice and peace in the Nigeria context. In Olupona, J.K (ed.). Religion and Peace in multi-faith Nigeria. Ile-Ife: OAU press.

Marighare, M. and Ferguson, J. (1965). Nigeria under the Cross. London: High press.

Naiwa, Osabon (2000, August 2). The Guardian. Sunday

Olupona, J.K (1992). The dynamics of religious and inter-faith dialogue in Nigeria. In Olupona, J.K (ed.). Religion and Peace in multi-faith Nigeria. Ile-Ife: OAU press.

Onyioha K.O.K. (1975, May 22). "Godianism”. A Paper Presented to the Conference of Traditional Religions of Nigeria Held in the Banquet Hall of the Lagos city Council. Godianism Deep thought (NKOWMII) ATR.

Oxtoby, W.G. (2002).World religions, Western traditions $\left(2^{\text {nd }}\right.$ Edn $)$. New York: Oxford University Press.

Scott, Hatfield (2006, 25-28 July). "Religion leadership and democratic sustenance in Africa". citing in Avo, Aderinwale. A paper delivered during African forum on religions and government held in Abuja.

Takaya, B.J. (1992). Religion politics and peace: resolving the Nigerian dilemma. In Olupona, J.K (ed.). Religion and Peace in multi-faith Nigeria. Ile-Ife: OAU press.

Wotogbe-Weneka, W. O. (2014). Themes in comparative religion. Port Harcourt: Stepson printing Press. 